\title{
New Races of Phytophthora sojae with Rps1-d Virulence
}

T. S. Abney, Plant Pathologist, Crop Production and Pathology Unit, Agricultural Research Service, U.S. Department of Agriculture, West Layafette, IN 47907; J. C. Melgar, Research Assistant, Botany and Plant Pathology Department, Purdue University, West Lafayette, IN 47907; T. L. Richards, Research Assistant, Crop Production and Pathology Unit, Agricultural Research Service, U.S. Department of Agriculture, West Layafette, IN 47907; and D. H. Scott, Professor, J. Grogan, Research Associate, and J. Young, Research Associate, Botany and Plant Pathology Department, Purdue University, West Lafayette, IN 47907

\begin{abstract}
Abney, T. S., Melgar, J. C., Richards, T. L., Scott, D. H., Grogan, J., and Young, J. 1997. New races of Phytophthora sojae with Rps1-d virulence. Plant Dis. 81:653-655.

Hypocotyl inoculations of differential soybean (Glycine max) cultivars were used to identify seven new physiologic races of Phytophthora sojae (syn. P. megasperma f. sp. glycinea). Five of the new races were virulent on soybeans with the Rps1-d allele, while four of the new races were virulent on soybeans with the Rps $1-\mathrm{k}$ allele. The Rps $1-\mathrm{k}$ and Rps 1 -d alleles provide resistance to a majority of the previously described races that cause Phytophthora root and stem rot. The seven new races were assigned race numbers $33,34,41,42,43,44$, and 45 since race numbers 35 through 40 were assigned to other new races recently identified in Ohio, California, Arkansas, and Iowa. The new races identified in this study constituted 14\% of the 1993 isolates evaluated from 27 counties in central and northern Indiana. Races 1 and 3 were the most prevalent, representing 31 and $26 \%$ of the $P$. sojae isolates identified in 1993. Races 4, 6, 7, 8, 9, 13 , 28 , and 29 each constituted 2 to $6 \%$ of the 1993 isolates. Other races identified among the 1993 isolates included races $19,21,25$, and 30 .
\end{abstract}

Awareness of Phytophthora root rot of soybeans (Glycine max (L.) Merr.) has increased since 1990. Several new races of Phytophthora sojae M. J. Kaufmann \& J. W. Gerdemann $(4,6)$ that infect soybean plants in the Midwest area of the U.S. were recently identified in Indiana (T. S. Abney, unpublished) and Ohio (10). All of these new races isolated from plant samples obtained in 1990 to 1992 were virulent on soybeans with the Rps $1-\mathrm{k}$ allele, using the hypocotyl inoculation method. Evaluation of the virulence formulas (10) for the $P$. sojae races reported prior to 1990 (i.e., races 1 to 27) demonstrates that $R p s 1-\mathrm{k}$ or $R p s 1-\mathrm{d}$ could be used to control a majority of the races that cause root and stem rot. The Rps $1-\mathrm{k}$ allele identified in Kingwa and transferred to Williams has been widely used in breeding programs since 1981, whereas the Rps1-d allele identified in PI 103091 has rarely been used.

Information on the race situation or inoculum potential for this disease in soybean production areas is limited. Data documenting the races of $P$. sojae isolated

Corresponding author: T. A. Abney

E-mail: abney@btny.purdue.edu

Accepted for publication 4 March 1997

Publication no. D-1997-0425-04R

This article is in the public domain and not copyrightable. It may be freely reprinted with customary crediting of the source. The American Phytopathological Society, 1997. from diseased soybeans in growers fields are important, but are also somewhat limited. Recovery of the pathogen from field plants in various stages of disease development is problematic, and the selectivity cultivars and specific Rps alleles impose also presents a potential bias on data obtained by sampling diseased plants randomly collected in growers' fields. Therefore, additional isolations of $P$. sojae from soil with the soybean seedling bioassay method (10) are needed to enhance the identification of races. In this report, physiologic races found in 1993 are identified and compared with races previously reported in Indiana. Several new $P$. sojae races are proposed. The reactions of differential cultivars to the new races and frequency of races isolated in Indiana soybean production areas are presented.

\section{MATERIALS AND METHODS}

Seventy isolates of $P$. sojae from field plants with symptoms of Phytophthora rot $(6,11)$ and 230 isolates from soil were collected in 1993 from producers' soybean fields and experimental soybean nurseries in Indiana. The soil samples from 80 fields in 27 counties were collected primarily in low areas of fields that had a history of Phytophthora damage in 1990 to 1992 and/or in areas of fields that had plants with chlorotic foliage and somewhat stunted growth in 1993. Soil samples were collected and $P$. sojae isolated with the Sloan soybean seedling bioassay method, using techniques described by Schmitthen- ner et al. (10). Isolations were made from the margin of diseased areas of stem or root tissue. Tissue samples were surface disinfected, and transferred to potato dextrose agar (PDA) and to the selective culture media (PRA) as previously described (8). The isolates collected in 1993 were tentatively identified as $P$. sojae $(4,6)$ by comparing colony characteristics and oospores on PDA and oatmeal agar (OA) to known isolates of $P$. sojae.

Inoculum was prepared by growing single oospore isolates on $\mathrm{OA}$ in petri plates in an unlighted cabinet at $24^{\circ} \mathrm{C}$ for 2 to 4 weeks. Inoculations were performed by the standard hypocotyl method (8), using $2 \times 2$ $\mathrm{mm}$ pieces of mycelia with abundant oospores, and the wound was covered with petrolatum to prevent desiccation of the inoculum and host tissue. Ten 7-day-old seedlings of soybean differentials $(1,2,10)$ representing different Rps alleles (Rps1-a, Rps1-b, Rps1-c, Rps1-d, Rps1-k, Rps3a, $R p s 6, R p s 7$, and $r p s$ ) were inoculated with each isolate and grown in the greenhouse at 24 to $27^{\circ} \mathrm{C}$ with supplemental fluorescent and incandescent light. Disease reactions of the differential cultivars were recorded 7 days after inoculation. The races were identified on the basis of a susceptible (plants killed) or a resistant (no effect) reaction of 60 to $70 \%$ of the soybean differentials in the tests. Inoculation tests were conducted four times for the new races and two times for the previously reported races.

\section{RESULTS AND DISCUSSION}

The differential virulence data for seven new physiologic races of $P$. sojae with eight different Rps alleles are listed in Table 1. Differential responses of the new physiologic races are distinctly different from the responses of races 1 to 32 $(1,2,7,10)$ and responses of the Ohio isolate (race 35) discussed by A. F. Schmitthenner at the 1995 University of Wisconsin Phytophthora Workshop, the two Japanese isolates (races 36, 37) reported by Förster et al. (3), the two Arkansas isolates (races 38, 39) reported by Henry and Kirkpatrick (5), and the Iowa isolate reported by Yang et al. (12). Since the Iowa isolate was not assigned a race number in the initial publication, it is being designated as race 40 (virulence 
formula $=1 \mathrm{a}, 1 \mathrm{c}, 1 \mathrm{~d}, 1 \mathrm{k}, 7)$ in this report. Race numbers 33 and 34 were reserved for the responses of two Indiana isolates also discussed at the University of Wisconsin Phytophthora Workshop. The results of repeated inoculation tests with each of the new races from Indiana were similar. Seven new race phenotypes are presented in Table 1. Isolates with the virulence formula $1 \mathrm{a}, 1 \mathrm{~b}, 1 \mathrm{c}, 1 \mathrm{~d}, 1 \mathrm{k}, 7$ were designated race 33 and isolates with the virulence formula $1 \mathrm{a}, 1 \mathrm{k}, 7$ were designated race 34 . Other unique isolates A41 (1a,1b, 1d,1k,7), A42 (1a,1d,3a,7), A43 (1a,1c, 1d,7), A44 (1a,1d,7), and A45 $(1 \mathrm{a}, 1 \mathrm{~b}, 1 \mathrm{c}, 1 \mathrm{k}, 6,7)$ were designated races $41,42,43,44$, and 45 , respectively.

Table 1. Virulence formulas and reaction of differential soybean cultivars to new races of Phytophthora sojae found in Indiana

\begin{tabular}{|c|c|c|c|c|c|c|c|c|c|}
\hline \multirow[b]{2}{*}{ Race $^{\mathbf{a}}$} & \multirow[b]{2}{*}{ Virulence formula $^{\mathbf{b}}$} & \multicolumn{8}{|c|}{ Susceptibility of cultivars with different $R p s$ alleles ${ }^{c}$} \\
\hline & & 1-a & 1-b & 1-c & 1-d & $1-k$ & 3-a & 6 & 7 \\
\hline A33 & $1 \mathrm{a}, 1 \mathrm{~b}, 1 \mathrm{c}, 1 \mathrm{~d}, 1 \mathrm{k}, 7$ & $\mathrm{~S}^{\mathrm{d}}$ & $\mathrm{S}$ & $\mathrm{S}$ & $\mathrm{S}$ & $\mathrm{S}$ & & & $\mathrm{S}$ \\
\hline A34 & $1 \mathrm{a}, 1 \mathrm{k}, 7$ & $\mathrm{~S}$ & & & & $\mathrm{~S}$ & & & $\mathrm{~S}$ \\
\hline A41 & $1 \mathrm{a}, 1 \mathrm{~b}, 1 \mathrm{~d}, 1 \mathrm{k},, 7$ & $\mathrm{~S}$ & $\mathrm{~S}$ & & $\mathrm{~S}$ & $\mathrm{~S}$ & & & $\mathrm{~S}$ \\
\hline A42 & $1 \mathrm{a}, 1 \mathrm{~d}, 3 \mathrm{a}, 7$ & $\mathrm{~S}$ & & & $\mathrm{~S}$ & & $\mathrm{~S}$ & & $\mathrm{~S}$ \\
\hline A43 & $1 \mathrm{a}, 1 \mathrm{c}, 1 \mathrm{~d}, 7$ & $\mathrm{~S}$ & & $\mathrm{~S}$ & $\mathrm{~S}$ & & & & $\mathrm{~S}$ \\
\hline A44 & $1 \mathrm{a}, 1 \mathrm{~d}, 7$ & $\mathrm{~S}$ & & & $\mathrm{~S}$ & & & & $\mathrm{~S}$ \\
\hline A45 & $1 \mathrm{a}, 1 \mathrm{~b}, 1 \mathrm{c}, 1 \mathrm{k}, 6,7$ & $\mathrm{~S}$ & $\mathrm{~S}$ & $\mathrm{~S}$ & & $\mathrm{~S}$ & & $\mathrm{~S}$ & $\mathrm{~S}$ \\
\hline
\end{tabular}

${ }^{a}$ A series from T. S. Abney (unpublished), sequence starts with the last published race by Schmitthenner et al. (10), but skips the following numbers: 35 (number reserved for new race from Ohio, A. F. Schmitthenner, unpublished); 36 and 37 (new races reported by Forster et al. from Japan [3]); 38 and 39 (new races reported by Henry and Kirkpatrick from Arkansas [5]); and 40 (number assigned in this paper for new race from Iowa, reported by Yang et al. [12]).

${ }^{\mathrm{b}}$ Listing of defeated Rps alleles (1a,1b,1c,1d,1k,3a,6,7).

${ }^{c}$ Rps 1-a in Haro12, 1-b in Haro13, 1-c in Harosoy isoline L85-129, 1-d in Haro16, 1-k in cv. Williams-82 and Resnik, 3-a in PI 171442, 6 in cv. Altona, 7 in cv. Harosoy, and 1-a,7 in cv. Harosoy 63.

${ }^{\mathrm{d}} \mathrm{S}=>60 \%$ of hypocotyl inoculated plants killed.

Table 2. Phytophthora sojae races reported in Indiana between 1973 and 1979 and in 1993

\begin{tabular}{|c|c|c|c|c|}
\hline \multirow[b]{2}{*}{ Race $^{\mathbf{a}}$} & \multirow[b]{2}{*}{ Virulence formula ${ }^{b}$} & \multirow[b]{2}{*}{ 1st year reported } & \multicolumn{2}{|c|}{ Races isolated } \\
\hline & & & 1973 to $1979(\%)^{\mathrm{c}}$ & $1993(\%)^{d}$ \\
\hline 1 & 7 & 1958 & 17 & 31 \\
\hline 3 & $1 \mathrm{a}, 7$ & 1978 & 48 & 26 \\
\hline 4 & $1 \mathrm{a}, 1 \mathrm{c}, 7$ & 1980 & 3 & 6 \\
\hline 5 & $1 \mathrm{a}, 1 \mathrm{c}, 6,7$ & 1978 & $<1$ & 0 \\
\hline 6 & $1 \mathrm{a}, 1 \mathrm{~d}, 3 \mathrm{a}, 6,7$ & 1975 & 0 & $2^{\mathrm{e}}$ \\
\hline 7 & $1 \mathrm{a}, 3 \mathrm{a}, 6,7$ & 1976 & 18 & 3 \\
\hline 8 & $1 \mathrm{a}, 1 \mathrm{~d}, 6,7$ & 1978 & 2 & 2 \\
\hline 9 & $1 \mathrm{a}, 6,7$ & 1978 & 12 & 3 \\
\hline 13 & 6,7 & 1978 & $<1$ & 2 \\
\hline 19 & $1 \mathrm{a}, 1 \mathrm{~b}, 1 \mathrm{c}, 1 \mathrm{~d}, 1 \mathrm{k}, 3 \mathrm{a}$ & 1993 & 0 & $<1$ \\
\hline 21 & $1 a, 3 a, 7$ & 1978 & $<1$ & $<1$ \\
\hline 22 & 1a, $1 \mathrm{c}, 3 \mathrm{a}, 6,7$ & 1980 & $<1$ & 0 \\
\hline 25 & $1 \mathrm{a}, 1 \mathrm{~b}, 1 \mathrm{c}, 1 \mathrm{k}, 7$ & 1984 & $<1$ & 1 \\
\hline 28 & $1 \mathrm{a}, 1 \mathrm{~b}, 1 \mathrm{k}, 7$ & 1993 & 0 & 6 \\
\hline 29 & $1 \mathrm{a}, 1 \mathrm{~b}, 1 \mathrm{k}, 6,7$ & 1993 & 0 & 4 \\
\hline 30 & $1 \mathrm{a}, 1 \mathrm{~b}, 1 \mathrm{k}, 3 \mathrm{a}, 6,7$ & 1993 & 0 & $<1$ \\
\hline New & Variable & 1993 & 0 & 14 \\
\hline
\end{tabular}

${ }^{a}$ Numerical races according to Schmitthenner et al. (10). All races are virulent on universal suscepts (rps) such as Sloan or Haro(1-7)1. New races are other phenotypes with virulence patterns different from races 1-32.

${ }^{\mathrm{b}}$ Listing of defeated Rps alleles (1a,1b,1c,1d,1k,3a,6,7).

c Year first isolated in Indiana and percentage reported 1973 to 1979 according to Laviolette and Athow (8), except for race 25 according to Layton et al. (9) and races 19, 28, 29, and 30, which were identified by the authors.

${ }^{d}$ Percentage for races in 1993 based on 300 isolates from plant and soil samples collected in central and northern Indiana.

${ }^{\mathrm{e}}$ Identification of race 6 was not verified due to the inconsistent reaction involving Rps1-d. was most similar to race $21(1 \mathrm{a}, 3 \mathrm{a}, 7)$. Race 43 (1a,1c,1d,7), based on eight isolates from Allen, Boone, Carroll, Randolph, Tipton, and Wabash counties, was most similar to race 4 (1a,1c,7). Race 44 (1a,1d,7), based on 15 isolates from Blackford, Carroll, Cass, Clinton, Jay, Randolph, Tipton, Wabash, and Wells counties, was most similar to race 3 (1a,7). Race 34 $(1 \mathrm{a}, 1 \mathrm{k}, 7)$, based on five isolates from Delaware, Hamilton, Jasper, Madison, and Tipton counties, was most similar to race $28(1 \mathrm{a}, 1 \mathrm{~b}, 1 \mathrm{k}, 7)$ and race $3(1 \mathrm{a}, 7)$, except for the Rps 1-b and 1-k reactions, respectively. Isolates of races 34,43 , and 44 are also similar to phenotypes (H29, H19, and $\mathrm{H} 17$, respectively) identified in Ohio as early as 1981 (10). The H29 (1a,1k), H19 (1a,1c,1d), and H17 (1a,1d) isolates were not saved and were not named as races since the Rps7 reaction was not evaluated. Race $45(1 \mathrm{a}, 1 \mathrm{~b}, 1 \mathrm{c}, 1 \mathrm{k}, 6,7)$ was isolated only from Wells County and was most similar to race $29(1 \mathrm{a}, 1 \mathrm{~b}, 1 \mathrm{k}, 6,7)$ and race 25 (1a,1b,1c,1k,7), except for the Rps 1-c and 6 reactions, respectively.

At least two different Rps alleles were identified that confer resistance to each of the new $P$. sojae races. Soybean cultivars with the Rps3a or Rps6 allele were resistant to races $33,34,41,43$, and 44 , whereas only one of these alleles conferred resistance to races 42 and 45 . The Rps 1 -d and Rps $3 \mathrm{a}$ alleles conferred resistance to races 34 and 45 . The Rps $1-\mathrm{b}, R p s 1-\mathrm{k}$, and $R p s 6$ alleles were resistant to races 42,43 , and 44 . Races $34,41,42$, and 44 were also controlled by the Rps 1 -c allele.

$P$. sojae races previously reported in Indiana and races identified in 1993 from diseased field plants collected in 11 counties and from Sloan seedlings growing in soil collected in 27 central and northern Indiana counties are listed in Table 2. All races previously reported in Indiana except for races 5 and 22 were identified among the 300 isolates collected in 1993. Races $19,28,29$, and 30 have not been reported in Indiana previously. Among the 1993 plant and soil isolates, races 1 and 3 were the most prevalent, representing 31 and $26 \%$ of the isolates, respectively. Races 4, 6, 7, 8, 9, 13, 28 , and 29 each constituted 2 to $6 \%$ of the isolates. The new races constituted $14 \%$ of the isolates.

Race 3 was the most prevalent (48\%) among the 1973 to 1979 isolates in Indiana (8). Races 1, 7, and 9 constituted 17, 18 , and $12 \%$ of the isolates, respectively. Races virulent on Rps1-k were not reported in the midwestern states until 1984 (10). The Rps $1-\mathrm{k}$ allele identified in Kingwa has been widely used in breeding programs since 1981 and could therefore constitute a selection pressure for $P$. sojae races virulent on soybeans with the Rps 1 -k allele. The Rps 1 -d allele identified in PI 103091 has rarely been used as a source of resistance and would therefore produce very little selection pressure 
for races virulent on soybeans with the Rps 1-d allele.

The 1993 isolates of races previously reported in Indiana had reaction patterns on differentials that were in agreement with previous race identifications $(2,10,11)$. All of the races except race $6(1 \mathrm{a}, 1 \mathrm{~d}, 3 \mathrm{a}, 6,7)$ were highly pathogenic on susceptible cultivars, and generally seedlings were 90 to $100 \%$ healthy or 90 to $100 \%$ dead. The susceptible reactions of soybean seedlings with the Rps1-d allele were inconsistent when inoculated with race 6 isolates. Laviolette and Athow (8) suggested race 6 was an invalid race because of the inconsistent reaction involving the Rps1-d allele.

This and previous research $(1,8,10,12)$ demonstrate the presence of at least 28 physiologic races of $P$. sojae that attack soybeans in the Midwest. Several of the races reported in Mississippi and other southern states have not been reported in the Midwest. Awareness of the presence of these races and the identification of parental lines resistant to the new races should be used in soybean breeding programs to minimize soybean yield losses.

\section{ACKNOWLEDGMENTS}

Contribution of the Agricultural Research Service, U.S. Department of Agriculture, in cooperation with the Purdue Agricultural Experiment Station, West Lafayette, IN. Supported in part by the Indiana Soybean Development Council.

\section{LITERATURE CITED}

1. Athow, K. L. 1987. Fungal diseases. Pages 687-727 in: Soybeans; Improvement, Production and Uses. J. R. Wilcox, ed. Am. Soc. Agron., Madison, WI.

2. Buzzell, R. I., and Anderson, T. R. 1992. Inheritance and race reaction of a new soybean Rps1 allele. Plant Dis. 76:600-601

3. Förster, H., Tyler, B. M., and Coffey, M. D. 1994. Phytophthora sojae races have arisen by clonal evolution and by rare outcrosses. Mol. Plant-Microbe Interact. 7:780-791.

4. Hansen, E. M., and Maxwell, D. P. 1991. Species of the Phytophthora megasperma complex. Mycologia 83:376-381

5. Henry, R. N., and Kirkpatrick, T. L. 1995. Two new races of Phytophthora sojae, causal agent of Phytophthora root and stem rot of soybean, identified from Arkansas soybean fields. Plant Dis. 79:1074.

6. Hildebrand. S. S. 1959. A root and stalk rot of soybeans caused by Phytophthora megasperma Drechsler var. sojae var. nov. Can. J. Bot. 37:927-957.

7. Keeling, B. L. 1984. A new physiologic race of Phytophthora megasperma f. sp. glycinea. Plant Dis. 68:626-627.

8. Laviolette, F. A., and Athow, K. L. 1981 Physiologic races of Phytophthora megasperma f. sp. glycinea in Indiana, 1973-1979. Plant Dis. 65:884-885.

9. Layton, A. C., Athow, K. L., and Laviolette, F. A. 1986. New physiologic race of Phytophthora megasperma f. sp. glycinea. Plant Dis. 70:500-501.

10. Schmitthenner, A. F., Hobe, M., and Bhat, R. G. 1994. Phytophthora sojae races in Ohio over a 10-year interval. Plant Dis. 78:269276.

11. Sinclair, J. B., and Backman, P. A., eds. 1989 Compendium of Soybean Diseases. 3rd ed American Phytopathological Society, St. Paul, MN.

12. Yang, X. B., Ruff, R. L., Meng, X. Q., an Workneh, F. 1996. Races of Phytophthora sojae in Iowa soybean fields. Plant Dis. 80 $1418-1420$ 